\begin{tabular}{|c|c|}
\hline local wisdom & $\begin{array}{c}\text { LOCAL WISDOM, } 11 \text { (2): 132-137, } 2019 \\
\text { Local Wisdom Scientific Online Journal } \\
\text { ISSN: 2086-3764 }\end{array}$ \\
\hline
\end{tabular}

\title{
Revitalization Concept Patirtan Sites as a Sustainable Spiritual Tourism in Malang, East Java
}

\author{
Junianto $^{1 *}$, Rosalia Niniek Sri Lestari ${ }^{2}$, Achmad Tutut Subadyo ${ }^{3}$, \\ 1Department of Architecture, Faculty of Engineering, University of Merdeka Malang, Indonesia \\ 2Department of Architecture, Faculty of Engineering, University of Merdeka Malang, Indonesia \\ 3Department of Architecture, Faculty of Engineering, University of Merdeka Malang, Indonesia \\ Corresponding Author: : junianto@unmer.ac.id
}

\begin{tabular}{|c|c|}
\hline & Abstract \\
\hline $\begin{array}{l}\text { Keywords: } \\
\text { malang, patirtan, } \\
\text { revitalization, site. }\end{array}$ & $\begin{array}{l}\text { The Patirtan site is a legacy of the ancient Singhasari kingdom in Malang, has } \\
\text { a high historical value. The existence of the Patirtan site is related to the } \\
\text { source of holy water (amerta), and is considered sacred by the community. } \\
\text { The use and development of the Patirtan site have tended to be partial and } \\
\text { contrary to the concept of conservation. The revitalization of Patirtan site in } \\
\text { Malang is the use of historical heritage in the form of bathing pools, for } \\
\text { religious self-cleaning activities. Spiritual tourism activities, as a form of } \\
\text { human relations with God, through traditional rituals, occur at the sites of } \\
\text { temples and Patirtan in Malang, East Java. Spiritual tourism actors in several } \\
\text { Patirtan sites in the Malang region are the preserver of the Nusantara culture, } \\
\text { originating from Java and Bali. This revitalization study, carried out by } \\
\text { descriptive method, through fact-finding with the proper interpretation of } \\
\text { people's attitudes, people's spiritual behaviour and phenomena on the } \\
\text { Patirtan site. There are three cases of Patirtan site in Malang, which is quite } \\
\text { significant to be used as a spiritual tourism destination, namely Sumberawan } \\
\text { Temple, Patirtan Watugede and Widodaren water source. Through historical } \\
\text { studies, exploring ritual activities at Patirtan sites in Malang, then analyzing } \\
\text { the physical character and function of Patirtan's sites, the concept of } \\
\text { revitalization was then formulated. }\end{array}$ \\
\hline
\end{tabular}

@ 2017 The Authors. Published by GKAK UNMER Malang

*Corresponding Author: junianto@unmer.ac.id 


\section{Introduction}

\section{Patirtan Site and Spiritual Tourism Activities in Malang}

The Patirtan site is of high historical value, many are found in the district of Malang. The historical and cultural traces of the Malang region are related to the great kingdoms of East Java, such as the ancient kingdom of Singhasari, the Medang kingdom and the Majapahit kingdom. The existence of Patirtan sites in the district of Malang, accompanied by the background of the existence of holy water sources (Junianto, 2016).

During the time of the ancient kingdom, the function of Patirtan was not only as a bathing place or bathing pool but more specifically as a place for ceremonies or ritual cleansing. The source of water that comes out in the places of the Patirtan pond is considered by the community as holy water (amerta). The values of life and cultural beliefs of the people are related to the cultural background that is embraced and developed from their daily lives (Wurianto, 2015). Culture is always sourced from the kingdom, as the centre of the life orientation of its people. Javanese culture, especially in the life of the people of East Java, originated from the kingdoms of Singhasari and Majapahit. Patirtan sites that are of historical value are places that are considered sacred and tend to be more protected from damage caused by human factors.

In the context of area protection, unique characteristics such as the Patirtan site are known for the sacred natural sites concept which has the potential to be beneficial for the effective management of a protected area (IUCN, 2008). The Patirtan site in the district of Malang is located in a community with a strong Javanese culture. The positive role of sacred sites in supporting the management of protected areas is the findings of (Nurlinda R., 2012) research on the Nusa Gede Panjalu Nature Reserve, (Kosmaryandi, 2012) in Kayan Mentarang and Wasur National Parks, and(Pratiekto, 2013) in Ujung Kulon National Park. Research on the national park status of the World Heritage Site, the activities of visits to sacred places has long been part of the culture of the local community called zarah (pilgrimage).

East Java region, there are many people who still preserve culture. The culture is grouped in different and unique sub-cultures. These cultural differences form a distinctive feature for the region. Traditional culture is a culture that has existed for a long time ago, which was guarded by the people and preserved. Cultural heritage is one form of expression of harmony, harmony and balance between physical-geographic conditions, the environment in which they live. A cultural environment is also a place of life activities and the development of sacred ceremonies that are based on the values of the beliefs held by the community and the rules of the sacral tradition, which he believes.

The ritual ceremony tradition, as ancestral cultural heritage, must always be preserved. The purpose of this kind of preservation is one of the efforts of the community in maintaining the traditions that still exist, so as not to become extinct. On the other hand, the development of the life of the city civilization, increasingly rapidly, tends to shift the ancestral cultural traditions. Along with the rapid development of civilization, it turns out there are still many cultural conservation communities in the district of Malang, who perform rituals of ancestral heritage. This activity is in the form of spiritual tourism. One place that is a spiritual tourist attraction is the Patirtan site. There are four places on the Patirtan site that are still visited by many people for spiritual tourism, namely the Polaman pool, Sendang Widodaren, the Sumberawan and Patirtan Watugede temples (Junianto, 2016). Preservation of the culture or tradition that exists in the community, a system that involves various parties, both from the community around the Patirtan site, spiritual tourism practitioners and from the government 
is needed. With the involvement of various parties in the revitalization process, it becomes a concept of sustainable conservation.

\section{Method}

The methods used in this study consist of two parts. Those are data compilation methods and data analysis methods.

\section{Method of collecting data}

This research is qualitative descriptive, with primary data collection methods, through:

- To get a direct picture, the current physical condition is carried out with a field survey.

- Questionnaires are conducted to capture people's preferences for the needs of ritual attractions, especially at the Patirtan site.

- Observations are made, regarding the function of the Patirtan site and the spatial arrangement in the Patirtan Baths.

- Interview with patirtan site manager, discussing historical, folklore and site users of Patirtan.

As for secondary data collection, done through:

- Collecting data regarding the development of the existence and character of the patirtan site, through searching for images from the Center for Cultural Heritage Conservation (BPCB).

- Literature studies: journals, government documents, seminar material, print media articles and electronic media.

\section{Data analysis method}

From the compiled data, interpretation analysis is carried out with qualitative analysis techniques. Analysis of characteristics, functions, historical values and community preferences towards Patirtan sites, is used to reveal the value of Patirtan site integrity.

\section{Discussion and Interpretation}

Based on field observations in four cases of the Patirtan site in Malang district, interviews with resource persons and historical studies can be described in the pattern of spiritual tourism activities. Spiritual tours on the site Patirtan Sendang Widodaren, Sumberawan, Watugede Baths and Polaman ponds were carried out by Javanese people who still strongly believed in the teachings of ancestral rituals. From the results of the fourth study of the Patirtan site in Malang, which became the research case, there were six types of ritual activities, namely :

- Rituals for taking "holy water" (amerta).

- Meditation rituals at water sources.

- Ritual bathing in a water source.

- The ritual dance in the Patirtan pond.

- Ceremony ritual offerings.

The ritual ceremony in the form of taking 'holy water' (amerta) was carried out at the site of the Patirtan water source Widodaren, the water source Patirtan Watugede and the Sumberawan temple. This ritual ceremony activity is carried out by the traditional Tengger community and the 'kejawen' community. The people descend from the Majapahit kingdom, many of whom live in the Tengger mountain region, covering the district. Malang Region, Pasuruan Region, Probolinggo Region. Lumajang Region (Subadyo, 2016). The community, 


\section{Revitalization Concept Patirtan Sites as a Sustainable Spiritual Tourism in Malang, East Java \\ Junianto, Rosalia Niniek Sri Lestari, Achmad Tutut Subadyo}

every year performs a ceremony called "grebek tirto aji", which is taking holy water in Widodaren's water source. The 'kejawen' community is domiciled in East Java, performs the retrieval ritual of 'holy water' (amerta) at Wendit, Patirtan Watugede and Sumberawan temple.

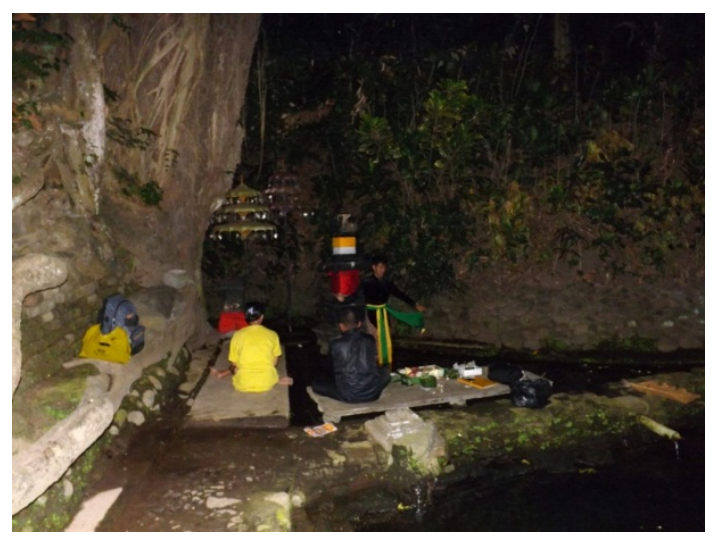

Figure 1. Ritual dance at Holy Water Source in Watugede, Singosari.

Water meditation rituals or 'bathing' in the water source of the Patirtan site, are carried out by several 'kejawen' communities, namely in the water source Widodaren (Wendit) and Patirtan Watugede pool. There are many 'kejawen' communities, who live in East Java, Central Java, DIY and DKI Jakarta. The community still believes and performs the ritual of ancestral heritage, through the source media 'holy water' (amerta) which is found on several Patirtan sites. The ritual of 'soaking' meditation in the source of 'holy water' is considered as purification of self and union with the maximum nature. Self-purification through "bathing" in the source of "holy water" (amerta) is considered to be a physical and spiritual cleansing of oneself.

The ritual of bathing at the source of the holy water (amerta) on the Patirtan site, is done by the community of 'kejawen', which is considered a ritual of self-cleansing. This ritual is carried out at Wendit, Sumberawan, Polaman and Patirtan Watugede water sources. In the ritual bathing at the Patirtan site, it is often done also with ritual dance, as a unit ceremony. The ritual ceremony offering, carried out by the community or community, in a particular theme. The ritual offerings ceremony was carried out by many cultural conservationists at the Sendang Widodaren site, in Sumberawan temple, Patirtan Watugede and in the Polaman pond. Ritual offerings are done by arranging flowers, burning incense and meditation. A number of communities, there are also those who perform ritual offerings with dance moves and walk around the site, as happened in Sumberawan and Patirtan temples Watugede. Meditation rituals, performed by the community community "Kejawen", as a form of selfunion with the universe. Meditation rituals, mostly carried out by the 'kejawen' community and the Javanese Hindu community on the Patirtan Watugede site, Patirtan Polaman Pond and Sumberawan temple. Meditational rituals are considered by the perpetrators as a process of self-union and communication with the universe. Meditation rituals are usually carried out by Javanese culture conservationists, at night. The pattern of spiritual tourism activities is formulated based on field observations, interviews with informants, occur in Patirtan rooms, namely: - Holy water source area (amerta); become the most sacred place, and is considered to have high energy. - Meditation area; the area around the site in the form of a courtyard or the lips of the Patirtan pond. - Ponds or buildings The Patirtan site baths, based on myths and historical information, are believed by the community to be sacred places. 


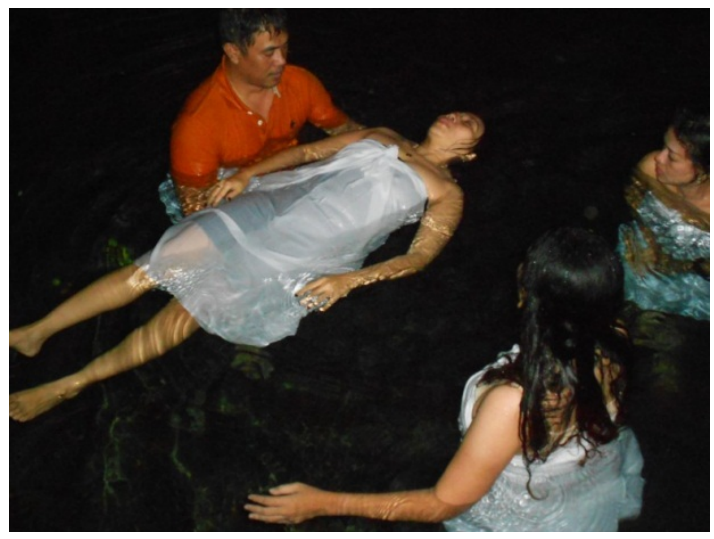

Figure 2. Water Meditation at Sendang Widodaren, Malang.

\section{The Patirtan Site Revitalization Concept}

Based on the results of the discussion on spiritual tourism behaviour, Patirtan site in the district of Malang, can be formulated the concept of Revitalization of the Patirtan site. Preservation of the Patirtan site in Malang district is significantly related to spiritual tourism activities, in addition to historical values. Based on the fourth integrity value of the Patirtan site at present, the government's policy on the Patirtan site, as well as the community's need for spiritual tourism space, can be formulated a conservation concept which includes physical, social, cultural and environmental elements in the form of ponds and temples, which are of high historical value. The concept of revitalizing Patirtan's site in a sustainable manner, including :

- Preservation of the building of the Patirtan site along with the bathing area, as a historical heritage, with the main element being a source of holy water (amerta).

- Cultural preservation, through fostering cultural conservation communities as actors and supporters of spiritual tourism. The ancestors of cultural preservation still undergo and believe in rituals at the places of Patirtan's site.

- Environmental conservation of the Patirtan site on a meso scale aims to maintain the purity of water sources that are considered sacred water (amerta) and control development in the area around the Patirtan site.

Preservation of the physical elements of the four Patirtan sites in the Malang district includes physical preservation of site buildings, preservation of the culture of the 'kejawen' community and Hindu Javanese, and environmental preservation, systemically sustainable. The preservation approach became the conceptual basis for the revitalization of Patirtan's site, in its function as a spiritual tourism object and as a historical heritage.

\section{Conclusion}

- Based on the study of four cases of the Patirtan site research, its sustainability is maintained by traditional Javanese or Kejawèn communities, to carry out the rituals of ancestral heritage. The people who use the Patirtan sites also feel an interest in maintaining the purity of the water source and the sanctity of the ritual place.

- Infrastructure development of the Patirtan site, in this case, the environmental road, is completed incrementally, by the community or the Culture and Tourism Office. 


\section{Revitalization Concept Patirtan Sites as a Sustainable Spiritual Tourism in Malang, East Java Junianto, Rosalia Niniek Sri Lestari, Achmad Tutut Subadyo}

Incremental infrastructure development has the potential to reduce regional sacred values, and may even reduce the site's historical value.

- The cultural values that developed in the traditional Javanese community (Kejawèn), as users of the Patirtan site complex, and have not been developed systematically. They build limited groups, individually, so organizing ritual events on Patirtan's sites cannot be scheduled in a structured manner, still incidental. This has an effect on the perpetrators of services and businesses (stalls) around the location, making it less developed.

\section{References}

Cooper C, Fletcher J, Gilbert D, Wanhill S. (1998). Tourism Principles and Practice. New York: Addison Wesley Longman Publishing.

[IUCN] International Union for Conservation of Nature. (2008). Sacred Natural Sites: Guides for Protected Area Managers. Gland (SW): Wild R, McLeod C, editor.

Junianto, Subadyo AT. (2016). Konsep Pelestarian Situs Patirtan di Malang Raya Sebagai Destinasi Wisata Spiritual. Malang: Prosiding Seminar Nasional IPLBI.

Kosmaryandi N. (2012). Pengembangan Zonasi Taman Nasional: Sintesis Kepentingan Konservasi Keanekaragaman Hayati dan Kehidupan Masyarakat Adat [disertasi]. Bogor: SP-IPB.

Nurlinda R. (2012). Peran Situs Keramat Alami Terhadap Efektivitas Pengelolaan Cagar Alam Nusa Gede Panjalu, Kabupaten Ciamis, Provinsi Jawa Barat [skripsi]. Bogor: IPB.

Pratiekto. (2013). Studi Permintaan Rekreasi Dan Strategi Pengembangan Ekowisata Spiritual Di TN Ujung Kulon. [skripsi]. Bogor: DKSHE-IPB.

Subadyo, AT. (2016). Arsitektur Pekarangan Suku tengger di Kantung Taman Nasional Bromo Tengger Semeru. Malang: Prosiding Seminar Nasional IPLBI.

Wurianto, AB. 2015. Aspek Budaya Pada Upaya Konservasi Air Dalam Situs Kepurbakalaan Dan Mitologi Masyarakat Malang, Malang: Jurnal Humanity, Vol. IV No. 2, hal 80-88 Publication. 